\title{
The Ordinary Deja Vu of a Rainy Morning $\cdot$ Jonathan Holden
}

It must be this way, too,

for the old men reading these pale

zeroes the rain keeps typing,

repeating perfectly in the pools-

the old men who have learned years ago

that weather is to be taken personally,

and who, though they are weary,

are today almost happy,

pleased with the way the rain

recites its adages,

something they had said once or written down,

as if the rain, by being so many,

defined them

as indefinite articles define a noun,

making possible a while longer

the singular.

And it must be here, surely,

in the singular, witness again

to that bitter green lacework in the elms,

the gossip of grasses drinking

this raw drizzle, adding

the sum of the rain's digits,

that we practice our aging

like the young illicit lovers as they undress.

On the border of the old country

they remember, now, its climate-

the hot monotony-

that it has no nationality.

And they know all that the old men

coming awake this morning

among the dark used furniture of a room

that resembles their room

on a day that resembles a forlorn April day

could know of deja vu. 
And they know where they are going they will be anonymous again.

They know, already, how the mask they draw on is common as the masks on their children asleep, the eyes lifted, birds

lost in the afternoon glare, leaving the face empty, a pure desertion.

Like the old men listening to the rain's adages,

the forsythia lit all this dark morning, they remember when they were plural. 